\title{
The Military and Legalism: A Response to Paul Sigmund
}

\author{
Gregory WeEks
}

University of North Carolina at Charlotte, United State

For a number of years a debate has emerged, centered on the question of whether civilian governments in Latin America have established supremacy over the armed forces. ${ }^{1}$ Although Argentina and Brazil initially received more attention in that regard, Chile is a tempting new example because retired General Augusto Pinochet, once a symbol of utter impunity (even entering the Chilean Senate), was transformed into a rumpled octogenarian, and for the most part disappeared from public view (though not from public discourse). His successors in the role of army Commanderin-Chief began speaking in new terms, eschewing Pinochet's intentionally inflammatory rhetoric, and even conceding that officers involved in human rights abuses could be brought before civilian courts. In this vein, Paul Sigmund comes to the conclusion-based in large part on criticism of my book on Chilean civil-military relations-that legalism has finally been restored to Chilean civil-military relations (Sigmund, 2003). My own contention is that although Chilean governments have made important strides, the legal foundations of military influence remained in place. I have elsewhere called this "inching toward democracy" (Weeks, 2003). In this short response, I will address both the criticism of my work and Professor Sigmund's own hypothesis.

I was surprised that Professor Sigmund stated that I do not define "salient interests" (Sigmund, 2003: 248). I will not belabor the point, but rather refer the reader to my book where between pages 13 and 17, I address that very issue in detail (Weeks, 2003b: 13-17). The military is interested in many issues, but attaches different importance to each interest, which in turn affects the way they react to the expansion of civilian authority over those issues.

Next, he claims that I "[do] not believe that the military will agree to the abolition of their appointed senators" (Sigmund, 2003: 248). In fact, I argue that the military designated senators (not the military as a whole) very likely will not vote themselves out of power. The sentence Sigmund quotes follows a discussion of the possibility of getting votes for such civil-military reform: "These votes potentially could come from members of the Concertación who are named designated senators, but the military senators will not likely acquiesce to dismantling the system" (Weeks, 2003: 161). The armed forces may, in the future, feel compelled to "agree to" the abolition of designated senators (perhaps as part of some political bargain) but as yet it has not come to pass.

Professor Sigmund also quotes my book with regard to the solution of the 1993 boinazo, which requires elaboration. The concessions did not simply involve "an agreement on the treatment of human rights cases" (Sigmund, 2003: 247). As I point out, they also involved firing a Subsecretary of War (Marcos Sánchez) that the army disliked, as well as compelling the Aylwin government to 
agree to expedite pending human rights cases while leaving no more such cases for the next government. Furthermore, I did not argue that the concessions alone were negative for the process of moving toward civilian supremacy. The full quote is that "The show of physical force-the deployment of troops in a public place-had set the stage for these concessions, therefore this incident did not augur well for the future of civilian supremacy" (Weeks, 2003: 90). I believe that assessment remains true, since deploying troops in battle regalia in downtown Santiago as a way to pressure the government is clearly negative for the democratization process.

Professor Sigmund points out correctly that the conviction and imprisonment of former DINA chief Manuel Contreras in 1995 was a tremendous moment for Chilean politics. At the same time, however, we must remain cognizant of the fact that the ejercicio de enlace and the boinazo remained fresh in the mind of President Eduardo Frei, who put human rights and military reform on the backburner. Contreras was an exceptional case, not the norm, as had even been true during the military regime, when Pinochet deliberately excluded Contreras (as well as anyone else involved in the murder of Orlando Letelier, a former cabinet official in the administration of President Salvador Allende, in Washington, DC) from the 1978 amnesty because of his involvement in murder in the United States had led to a serious conflict between the two countries.

Furthermore, although there is always a high degree of speculation when arguing a counterfactual, it is entirely possible that without an external shock-namely Pinochet's 1998 arrest in Great Britainthe Contreras case would have remained exceptional. There is no doubt that Pinochet's detention punctured the overall sense of military impunity in a way that Contreras' did not, so it is possible that in the absence of that external shock, more generals would have remained safely at home rather than facing charges. It is therefore arguable that the Contreras conviction should not be over-emphasized as setting the stage for the prosecution of human rights cases.

Yet there are important advances taking place in human rights. For example, in April 2004 the former head of the CNI (the successor to the DINA), faced charges of being responsible for the deaths of three Socialist Party members as part of the "Caravan of Death." ${ }^{2}$ The number of officers being taken to court and even imprisoned is reaching into the hundreds. The rule of law is proving strong, such that even senior officers of the military regime are standing before civilian courts. But does this mean that we can proclaim that legalism as a whole has been restored?

On the point of designated senators, Professor Sigmund argues that the debate itself is a sign that legalism has returned since my book was written (Sigmund, 2003: 249). Many military prerogative have become public issues at some point or another since 1990, debated openly (in fact, the Concertación had an ambitious platform in 1989), but although this is certainly an indication that protection of free speech is strong enough in Chile to criticize military interests (something not always evident when the criticism is aimed at the judiciary), it does not mean that the legal bases of civilian authority have been restored. The example of the Copper Law is instructive. In 2002, Defense Minister Bachelet announced she intended to begin discussing eliminating the law, which provides the military with a protected source of funding. Very soon, however, she publicly announced she was withdrawing the proposal and would not even give a timetable for its return to the civilmilitary agenda. ${ }^{3}$ I have not conducted interviews to determine what channels the military leadership

"Juan Guzmán procesa a ex Director de la CNI por asesinato de tres socialistas". La Tercera, April 30, 2004.

"Bachelet admite retraso en reformulación de Ley de Cobre." La Tercera, August 1, 2002. 
used to block the initiative, but the essential point is that debate alone does not re-establish legalism. Only democratic reform can accomplish that goal, and thus far very little reform has taken place.

Felipe Agüero argues that the two most important reforms will be reducing military influence over the National Security Council, and putting the power of firing commanders in chief back in the hands of the president (Agüero, 2003). To these I would add the designated senators, the copper law, reducing the scope of military justice, and increasing civilian oversight over the military's intelligence agencies. It is notable that in the case of the current discussions of the creation of a new national intelligence agency (the Agencia de Inteligencia Nacional) the proposal continues to grant each branch's intelligence services broad autonomy. Limiting these prerogatives will require amending the constitution and the organic law of the armed forces, which in turn requires congressional majorities that currently do not exist. If the designated senators are abolished, the task will be easier, but the binomial electoral system over-represents the right, so the support of at least some members of at least Renovación Nacional, and perhaps the Unión Demócrata Independiente as well, will be necessary for success. Thus, we can celebrate the return of democratic debate in Chile, but it is premature to announce the restoration of the legal foundations of civilian supremacy over the armed forces.

Citing Brian Loveman, Professor Sigmund asks rhetorically whether Chile should be labeled a "protected democracy." Loveman defines it as a situation "with the military institutions as the guarantors of the political and legal order and, implicitly, the adjudicators of their nations' common good, permanent interests, and national security requirements" (Loveman, 1999: 213). In addition to all the military prerogatives already discussed, the Chilean constitution clearly lays out the expanded role of the military. Article 90 states that the armed forces "existen para la defensa de la patria, son esenciales para la seguridad nacional y garantizan el orden institucional de la República." The current constitutional and legal order in Chile continues to provide significant areas of military tutelage, budgetary autonomy, and immunity from congressional oversight. In fourteen years since President Patricio Aylwin became the first elected president after almost seventeen years of dictatorship, it has not been possible to enact constitutional and legal reforms to alter these foundations of military involvement in Chilean politics.

Regarding Professor Sigmund's assertion that "the armed forces have now returned to the tradition of legalism and constitutionalism which characterized the military culture of Chile before 1970," it is also necessary to acknowledge the very different political and legal conditions of 1932-1970 versus 1990 to the present. After 1932, the military (especially the army) was humbled and humiliated after a series of disastrous military governments (including the Socialist Republic) and so at least part of its rejection of military rule was rooted in that experience. After 1990, the military has viewed its government with pride, arguing that it prevented a civil war and rebuilt the economy. The Milicia Republicana that Arturo Alessandri used to his advantage epitomized the military's failures, along with the budgetary punishments and the public's disdain, which disappeared only slowly; none of this, is evident in the current postauthoritarian era. But perhaps even more important is the difference between the constitutions that governed each era. The 1980 constitution grants more autonomy to the armed forces than its 1925 predecessor and its authors consciously crafted it that way. The document melded Chilean presidentialism, Diego Portales' "autocratic republic" and Cold War national security doctrine in a manner that politicized the armed forces unlike the 1925 
charter. If anything, "legalism" in Chile today simply means the legalization of the military's expanded role in politics.

Nonetheless, it is possible to conclude on a positive note. The very existence of debate on this issue is evidence of major advances in democratization since the transition to civilian rule. The civil-military discord that characterized Pinochet's last years as Commander in Chief has been replaced by dialogue-even over very sensitive issues-during the tenures of Generals Ricardo Izurieta and Juan Emilio Cheyre. Progress has indeed been made, but the road to civilian supremacy remains a long one.

\section{REFERENCES}

Agüero, Felipe. 2003. "30 años después: La ciencia política y las relaciones Fuerzas Armadas, Estado y sociedad”. Revista de Ciencia Política XXIII (2): 251-272.

Fitch, J. Samuel. 2001. "Military Attitudes toward Democracy in Latin America: How Do We Know If Anything Has Changed?" In Civil-Military Relations in Latin America: New Analytical Perspectives, edited by David Pion-Berlin. Chapel Hill: The University of North Carolina Press, 59-87.

Loveman, Brian. 1999. For la Patria: Politics and the Armed Forces in Latin America. Wilmington, DE: SR Books.

Sigmund, Paul. 2003. "The Chilean Military: Legalism Undermined, Manipulated, and Restored". Revista de Ciencia Política XXIII (2): 241-250.

Weeks, Gregory. 2003. "Inching Toward Democracy? President Lagos and the Chilean Armed Forces". Paper Presented at the 2003 Meeting of the Latin American Studies Association, Dallas, Texas.

Weeks, Gregory. 2003b. The Military and Politics in Postauthoritarian Chile. Tuscaloosa: The University of Alabama Press.

Gregory Weeks is professor at the Department of Political Science, University of North Carolina at Charlotte, United State. His research interests are Civil-Military Relations, Political Institutions and Democratization, U.S.-Latin American Relations and Chile. He is author of U.S.-Latin American Relations (under contract with Longman Publishers for publication in 2005) and The Military and Politics in Postauthoritarian Chile (Tuscaloosa: The University of Alabama Press, 2003).

(E-mail: gbweeks@email.uncc.edu) 